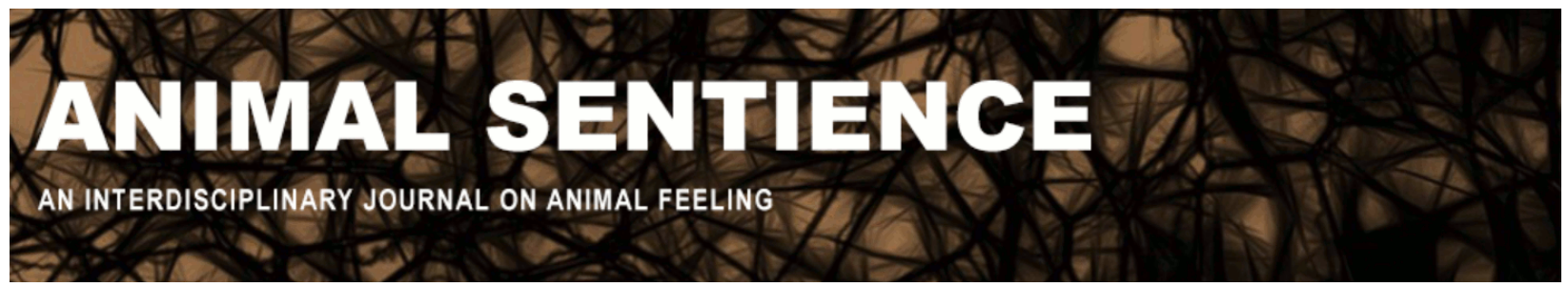

Fischer, Bob (2018) Individuals in the wild. Animal Sentience 23(8)

DOI: $10.51291 / 2377-7478.1382$

Date of submission: 2019-01-25

Date of acceptance: 2019-02-06

(c) (i)

This article has appeared in the journal Animal

Sentience, a peer-reviewed journal on animal

cognition and feeling. It has been made open access,

free for all, by WellBeing International and deposited

in the WBI Studies Repository. For more information,

please contact

wbisr-info@wellbeingintl.org.

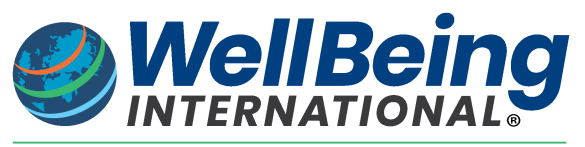

SOLUTIONS FOR PEOPLE, ANIMALS AND ENVIRONMENT 


\title{
Individuals in the wild
}

Commentary on Chapman \& Huffman on Human Difference

\author{
Bob Fischer \\ Department of Philosophy \\ Texas State University
}

\begin{abstract}
If many wild animals have net negative lives, then we have to consider how likely it is that the good for animals, considered as individuals, aligns with the good for species, or the climate, or the preservation of wild spaces.
\end{abstract}

\begin{abstract}
Bob Fischer, assistant professor in the Department of Philosophy at Texas State University, works on animal ethics and the epistemology of modality, and is co-director the Society for the Study of Ethics and Animals. Website
\end{abstract}

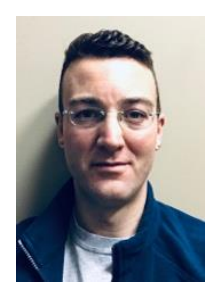

I'm sympathetic to much of what Chapman \& Huffman (2019) say. For instance, I agree that many arguments for human superiority are instances of motivated reasoning. I agree that the differences between human and nonhuman animals don't require us to postulate a hierarchy of importance: we can be different without being better. Moreover, I applaud C \& $\mathrm{H}$ for encouraging us to make positive changes in our relationships with nonhuman animals. Nevertheless, I worry that C \& H oversimplify some important issues. Here, l'Il just focus on one of them: namely, their suggestion that if we were to stop thinking that human beings are superior to nonhuman animals, we would be better positioned to address various problems like species loss, climate change, and deforestation.

It's tempting to think that our interests in the environment align with those of nonhuman animals, where the goal is more biodiversity, more wild spaces, and a more stable climate. But it isn't clear that this is so. This is because we tend to operate with what Oscar Horta (2010) calls "the idyllic view of nature." According to this view, nonhuman animals generally have lives worth living when left to themselves; most of them experience more pleasure than pain. But many have argued that this is false: see, e.g., Faria (2016), Faria and Paez (2015), Horta (2010, 2017), Ng (1995), and Tomasik (2015). On this alternative view, most animals live "net negative lives" - i.e., they experience more pain than pleasure - for reasons having little to do with human beings. Animals regularly starve, suffer from debilitating injuries and diseases, and find themselves the victims of predation. And when not facing these acute sources of pain, they are often stressed by their possibility: many animals live their lives on high alert, constantly having to be wary of deadly threats. Moreover, it's plausible that most animals don't live long enough to reach more secure positions in the food web where they are less vulnerable to predation. Consider that human beings are unusual in having so few offspring: as of 2017, the average woman has just under 2.5 
children in her lifetime. ${ }^{1}$ By contrast, elephants might have 6; mice, 40; some species of salmon, 17,000; and ocean sunfish, 300 million per year. Obviously, most of these animals die young.

A standard response is to argue for a duty to aid wild animals (see, e.g., Faria 2015, McMahan 2015, and Torres 2015). If nonhuman animals deserve the same moral consideration that we give to human beings - if, for instance, their interest in being free from pain is as significant, morally speaking, as our own - then we may well have a responsibility to mitigate or entirely prevent much of the suffering that occurs in the wild. (This, after all, is what we might conclude if human beings were suffering such fates in other countries.) But even if we deny this, the fact of wild animal suffering should be a consideration in our environmental efforts. If, for instance, implementing a particular policy would slightly improve things for human beings while significantly increasing the amount of suffering in nature, it seems that we have a good reason not to implement the policy.

In short, once we take the other animals seriously, we have to come to grips with the realities of their lives. And if many wild animals have net negative lives, then we have to consider how likely it is that the good for animals, considered as individuals, aligns with the good for species, or the climate, or the preservation of wild spaces. It may well turn out that animals fare best when there are many fewer of them, sparing them from having to compete so aggressively for resources. Or it may turn out that they fare best when heavily managed, perhaps through genetic interventions. Or it may turn out that they fare best when some species are eliminated entirely, such as certain kinds of parasites. In all these cases, valuing animals as individuals would be in tension with valuing biodiversity or the preservation of wildness. And depending on the net impact of climate change on biodiversity and wildness, there may be a tension with preventing climate change as well.

None of the above is an argument against viewing nonhuman animals as morally significant beings. None of it is an argument against ignoring the various ways in which we harm them. Finally, none of it is an argument for or against any particular environmental policy. All of it, however, should be a check on C \& H's optimism that they've put their finger on the solution to our environmental problems. Granted, it would be nice if the good for animals were to align with an anthropocentric vision of a healthy planet. But what's nice may not be so.

\section{References}

Chapman, C. A. and Huffman, M. A. (2018) Why do we want to think humans are different? Animal Sentience 23(1).

Faria, C. (2015) "Disentangling Obligations of Assistance: A Reply to Clare Palmer." Relations: Beyond Anthropocentrism, 3, 211-218.

Faria, C. (2016) Animal Ethics Goes Wild: The Problem of Wild Animal Suffering and Intervention in Nature. PhD thesis. Barcelona: Pompeu Fabra University.

Faria, C. and Paez, E. (2015) "Animals in Need: The Problem of Wild Animal Suffering and Intervention in Nature." Relations: Beyond Anthropocentrism, 3, 7-13.

Horta, O. (2010) "Debunking the Idyllic View of Natural Processes." Télos, 17, 73-88.

\footnotetext{
${ }^{1}$ https://data.worldbank.org/indicator/SP.DYN.TFRT.IN
} 
Horta, O. (2017) "Animal Suffering in Nature: The Case for Intervention." Environmental Ethics, 39, 261-279.

McMahan, J. (2015) “The Moral Problem of Predation." In Chignell, A., Cuneo, T. and Halteman, M. (Eds.), Philosophy Comes to Dinner: Arguments on the Ethics of Eating. London:

Routledge, pp. 268-294.

Ng, Y.-K. (1995) "Towards Welfare Biology: Evolutionary Economics of Animal Consciousness and Suffering." Biology and Philosophy, 10, 255-285.

Tomasik, B. (2015) "The Importance of Wild-Animal Suffering." Relations: Beyond Anthropocentrism, 3, 133-152.

Torres, M. (2015) "The Case for Intervention in Nature on Behalf of Animals: A Critical Review of the Main Arguments Against Intervention." Relations: Beyond Anthropocentrism, 3, 33-49. 